\title{
Analysis on Techno-Economic Benefits of a Strategically Placed Distributed Generator in a Radial Distribution System
}

\author{
S. Rama Krishna \\ P.G. Scholar \\ Electrical and Electronics Engineering \\ Sir C R Reddy College of Engineering, Eluru, \\ Andhra Pradesh, India-534007.
}

\author{
Injeti S. Kumar \\ Associate Professor \\ Electrical and Electronics Engineering \\ Sir C R Reddy College of Engineering, Eluru, \\ Andhra Pradesh, India-534007.
}

\begin{abstract}
Integration of alternative sources of energy into a network for distributed generation (DG) requires small-scale power generation technologies located close to the loads served. The move toward on-site distributed power generation has been accelerated because of deregulation and restructuring of the utility industry and the feasibility of alternative energy sources. DG technologies can improve power quality, boost system reliability, reduce energy costs, and defray utility capital investment. This paper presents techno economic analysis of optimally located and sized various DG technologies in a radial distribution system. The impact of DG on the system voltage profile and line losses is also evaluated. This has been accomplished by two parts, part one examine technical benefits of integration of a DG unit to different buses of distribution system and varying DG unit size in a 30 bus radial distribution system. Part two examine the implementation viability of the project; a detailed financial evaluation has been carried out for various DG technologies which are available in the market for commercial use. The results show that there is significant improvement in voltage profile, reduction in line loss and consequently the utility can gain financial benefits when DG is incorporated into the system.
\end{abstract}

\section{Keywords}

Distributed generation, emission, optimum location and sizing, techno-economic analysis etc...

\section{INTRODUCTION}

Studies have showed that as much as $13 \%$ of total power generated is wasted as losses at the distribution level [1]. As a result, loss reduction in distribution system is one great challenge to many utilities around the world. Reconfiguration and capacitor placement is the two major methods for loss reduction in distribution systems. Advances in generation technology, new directions in electric industry regulation and environmental emissions have favored a significant increase of DG. It is reported that $25 \%-30 \%$ newly built generation capacity around the world will be as DG [2]. Several DG technologies have reached in a developed stage allowing for a large scale implementation within existing electric utility system [3]. The development and growing interest in renewable sources of energy such as wind, solar, geothermal, biomass, small hydro etc, all over the world, make these technologies suitable for integration into distribution network [4]. In the last few years, there has been significant contribution to research in DG resource planning. Normally, DGs are integrated in the existing distribution system, and the planning studies have to be performed for optimal location and sizing of DGs to achieve maximum benefits. Inappropriate selection of the location and size of DG may lead to greater system loss than the loss without DG [5]. The contribution of DG on loss reduction is presented with the DG capacity, location and operating power factor [6]. A power flow algorithm has been developed based on the summation of currents backward-forward sweep technique [7]. Reconfiguration problem is solved through a heuristic methodology and loss allocation function based on the Z-bus method, is presented. A technique for evaluation of optimal power flow for the connection of DG is presented in [8]. The Genetic Algorithm (GA) based method to determine size and location is used in [9]. GA's are suitable for multi-objective problems like DG allocation, and can give near optimal results. A new heuristic approach for DG capacity investment planning from the perspective of a distribution company is presented [10]. Optimal sitting and sizing decisions for DG capacity is obtained through cost-benefit analysis approach based on a new optimization model. The model aims to minimize the distribution companies' investment and operating costs as well as payment towards loss compensation. A value based planning of DG placement method considering different constraint is presented in [11]. Optimal placement of DG considering economic operational limitations of DG is presented in [12]. A technique has been proposed in [13] to identify the impact of DG on power system. The analysis shows the optimal DG mix at various facility outage costs with and without emission restriction. 
Table 1. Variation of line loss with DG capacity and DG position

\begin{tabular}{|c|c|c|c|c|c|c|c|c|c|c|c|}
\hline \multirow{2}{*}{$\begin{array}{l}\text { Bus } \\
\text { No. }\end{array}$} & \multicolumn{11}{|c|}{ Capacity of DG in percentage of total load plus losses } \\
\hline & $0 \%$ & $10 \%$ & $20 \%$ & $30 \%$ & $40 \%$ & $50 \%$ & $60 \%$ & $70 \%$ & $80 \%$ & $90 \%$ & $100 \%$ \\
\hline 2 & 0.88188 & 0.86280 & 0.84562 & 0.83033 & 0.81692 & 0.80538 & 0.79569 & 0.78785 & 0.78184 & 0.77766 & 0.77529 \\
\hline 3 & 0.88188 & 0.84581 & 0.81359 & 0.78517 & 0.76051 & 0.73956 & 0.72229 & 0.70863 & 0.69858 & 0.69208 & 0.68909 \\
\hline 4 & 0.88188 & 0.82049 & 0.76628 & 0.71912 & 0.67884 & 0.64532 & 0.61842 & 0.59800 & 0.58394 & 0.57611 & 0.57440 \\
\hline 5 & 0.88188 & 0.79826 & 0.72524 & 0.66251 & 0.60975 & 0.56669 & 0.53304 & 0.50853 & 0.49293 & 0.48599 & 0.48748 \\
\hline 6 & 0.88188 & 0.77696 & 0.68637 & 0.60957 & 0.54601 & 0.49519 & 0.45664 & 0.42992 & 0.41462 & 0.41035 & 0.41674 \\
\hline 7 & 0.88188 & 0.76444 & 0.66794 & 0.59123 & 0.53323 & 0.49297 & 0.46955 & 0.46216 & 0.47004 & 0.49249 & 0.52888 \\
\hline 8 & 0.88188 & 0.75823 & 0.65994 & 0.58531 & 0.53284 & 0.50118 & 0.48909 & 0.49547 & 0.51933 & 0.55974 & 0.61587 \\
\hline 9 & 0.88188 & 0.75165 & 0.65326 & 0.58411 & 0.54192 & 0.52470 & 0.53069 & 0.55834 & 0.60625 & 0.67318 & 0.75802 \\
\hline 10 & 0.88188 & 0.74909 & 0.65230 & 0.58823 & 0.55405 & 0.54730 & 0.56588 & 0.60792 & 0.67178 & 0.75600 & 0.85927 \\
\hline 11 & 0.88188 & 0.74858 & 0.65376 & 0.59368 & 0.56516 & 0.56547 & 0.59227 & 0.64352 & 0.71742 & 0.81240 & 0.92704 \\
\hline 12 & 0.88188 & 0.74907 & 0.65659 & 0.60035 & 0.57687 & 0.58324 & 0.61693 & 0.67577 & 0.75784 & 0.86148 & 0.98520 \\
\hline 13 & 0.88188 & 0.84612 & 0.81677 & 0.79369 & 0.77676 & 0.76589 & 0.76095 & 0.76183 & 0.76843 & 0.78067 & 0.79843 \\
\hline 14 & 0.88188 & 0.84695 & 0.82176 & 0.80605 & 0.79954 & 0.80198 & 0.81313 & 0.83276 & 0.86064 & 0.89656 & 0.94033 \\
\hline 15 & 0.88188 & 0.84756 & 0.82464 & 0.81273 & 0.81149 & 0.82056 & 0.83963 & 0.86838 & 0.90654 & 0.95381 & 1.00994 \\
\hline 16 & 0.88188 & 0.84797 & 0.82627 & 0.81634 & 0.81779 & 0.83021 & 0.85324 & 0.88654 & 0.92978 & 0.98264 & 1.44085 \\
\hline 17 & 0.88188 & 0.76011 & 0.65709 & 0.57188 & 0.50360 & 0.45145 & 0.41469 & 0.39263 & 0.38464 & 0.39015 & 0.40858 \\
\hline 18 & 0.88188 & 0.74608 & 0.63326 & 0.54201 & 0.47108 & 0.41932 & 0.38571 & 0.36930 & 0.36924 & 0.38472 & 0.41502 \\
\hline 19 & 0.88188 & 0.73028 & 0.60715 & 0.51037 & 0.43811 & 0.38875 & 0.36082 & 0.35302 & 0.36417 & 0.39321 & 0.43918 \\
\hline 20 & 0.88188 & 0.71770 & 0.58705 & 0.48709 & 0.41537 & 0.36975 & 0.34835 & 0.34952 & 0.37177 & 0.41379 & 0.47439 \\
\hline 21 & 0.88188 & 0.70695 & 0.57064 & 0.46924 & 0.39964 & 0.35915 & 0.34544 & 0.35649 & 0.39053 & 0.44598 & 0.52144 \\
\hline 22 & 0.88188 & 0.69474 & 0.55315 & 0.45211 & 0.38745 & 0.35572 & 0.35394 & 0.37959 & 0.43049 & 0.50471 & 0.60058 \\
\hline 23 & 0.88188 & 0.68520 & 0.54086 & 0.44237 & 0.38450 & 0.36295 & 0.37413 & 0.41502 & 0.48303 & 0.57595 & 0.69182 \\
\hline 24 & 0.88188 & 0.67703 & 0.53229 & 0.43928 & 0.39145 & 0.38349 & 0.41109 & 0.47067 & 0.55919 & 0.67411 & 0.81320 \\
\hline 25 & 0.88188 & 0.67376 & 0.53059 & 0.44271 & 0.40265 & 0.40452 & 0.44352 & 0.51572 & 0.61785 & 0.74715 & 0.90124 \\
\hline 26 & 0.88188 & 0.67307 & 0.53197 & 0.44813 & 0.41358 & 0.42204 & 0.46848 & 0.54876 & 0.65946 & 0.79772 & 0.96109 \\
\hline 27 & 0.88188 & 0.67360 & 0.53498 & 0.45502 & 0.42537 & 0.43948 & 0.49212 & 0.57904 & 0.69671 & 0.84217 & 1.01295 \\
\hline 28 & 0.88188 & 0.76437 & 0.67071 & 0.59943 & 0.54914 & 0.51863 & 0.50679 & 0.51262 & 0.53519 & 0.57366 & 0.62727 \\
\hline 29 & 0.88188 & 0.76483 & 0.67447 & 0.60896 & 0.56662 & 0.54595 & 0.54564 & 0.56448 & 0.60138 & 0.65537 & 0.72554 \\
\hline 30 & 0.88188 & 0.76581 & 0.67919 & 0.61979 & 0.58558 & 0.57483 & 0.58597 & 0.61761 & 0.66849 & 0.73749 & 0.82359 \\
\hline
\end{tabular}


An improved analytical method is proposed in [14] to find the optimal sizes, optimal locations of various types of DG. It also presents the importance of operating DGs that are capable of delivering both real and reactive power at the proper power factor to achieve minimum loss. Hedayati.et.al. [15] proposed a method based on continuous power flow. In this method they first determine the most sensitive buses to voltage collapse. After that, the DG units with certain capacity will be installed in buses via an objective function and an iterative algorithm. However, these works does not discuss about viability of project implementation in terms of economics as well as environmental benefits.

\section{IDENTIFICATION OF OPTIMAL LOCATION AND CAPACITY OF DG}

To assess the impact of DG, the DG unit is connected to one of the buses at a time and its effect on bus voltage and line losses (real power) are studied. The location of DG is varied from bus 2 to bus 30 except bus 1 , since it is the source bus or sub-station bus. Note that addition of DG at bus 1 has no effect. Keeping the output DG capacity constant, the position of the DG is changed from bus 2 to bus 30 and the effects on the above parameters are observed. Then the DG capacity is increased in steps of $10 \%$ and the same procedure is carried out for each variation of the capacity (i.e. capacity of DG is equal to percentage of total load plus line loss). The optimal location of DG in terms of bus number is determined by the bus that yields minimum line loss. For each variation of DG capacity, line loss has been calculated. This procedure creates a set of solutions, out of all solutions the one that is optimal is chosen as the final solution (location and capacity of DG). The line losses for the system with variation of DG capacity are given in Table. 1. The effects of integration of DG were analyzed in the next section.

\section{INTEGRATION OF DG}

The location of DG is varied from bus 2 to bus 30 except bus 1 , since it is the source bus or sub-station bus. Note that addition of DG at bus 1 has no effect. For each location from bus 2 to bus 30 rated MW DG capacities is varied from $10 \%$ to $100 \%$ of the total load in steps of $10 \%$. For each case the total line loss in terms of percentage of total load and improvement in bus voltage is calculated. The results such as line loss for the test system with DG capacity for $10 \%$ to $100 \%$ of total load plus losses are given in Table. 1. It is observed that there is an appreciable reduction in line loss at the initial stages of DG addition, i.e., at $10 \%$ and $30 \%$ range and the losses further decreased as the size reaches to $60 \%$. Hence for optimal utilization, a DG should be so chosen that it has to operate within the range of $0 \%$ to $60 \%$ of total load plus losses. Optimal size and location of DG is also calculated for the test system is $60 \%$ of the total load plus losses and bus 21. Then the total line loss (in terms of total load) and improvement in voltage profile (p.u) are calculated. The results such as optimal capacity, optimal location and reduction in line loss for the test system are given in Table 2. Improvement in voltage profile and line loss profile for the test system with and without DG with respect to their locations are plotted in Fig 1 and Fig 2 for illustration. It is observed that there is an appreciable reduction in line loss and significant improvement in voltage profile.

Table 2. Summary of minimal line losses for variation of DG capacity and DG location

\begin{tabular}{|c|c|c|c|}
\hline Method & $\begin{array}{r}\% \text { DG } \\
\text { capacity }\end{array}$ & $\begin{array}{c}\text { DG } \\
\text { location }\end{array}$ & $\begin{array}{c}\text { Line } \\
\text { loss }(\mathrm{MW})\end{array}$ \\
\hline \multirow{11}{*}{ Analytical } & $0 \%$ & --- & 0.88188 \\
\hline & $10 \%$ & 27 & 0.67360 \\
\hline & $20 \%$ & 25 & 0.53059 \\
\hline & $30 \%$ & 24 & 0.43928 \\
\hline & $40 \%$ & 23 & 0.38450 \\
\hline & $50 \%$ & 22 & 0.35572 \\
\hline & $60 \%$ & 21 & 0.34544 \\
\hline & $70 \%$ & 20 & 0.34952 \\
\hline & $80 \%$ & 19 & 0.36417 \\
\hline & $90 \%$ & 18 & 0.38472 \\
\hline & $100 \%$ & 17 & 0.40858 \\
\hline
\end{tabular}

\section{COST BENEFIT ANALYSIS}

The approximate daily load curve of the test system is given in Fig 3. The load curve shows the amount of load in MW that the test system supplies throughout a day and is plotted in MW verses hours. From the curve the load demand varies from 5.5 MW during midnight hours, $10 \mathrm{MW}$ during day time to $13 \mathrm{MW}$ during evening hours. The average load demand found to be $8.7163 \mathrm{MW}$.

Table 3. Summary of selected DG capacities and line losses

\begin{tabular}{|c|c|c|c|}
\hline DG capacity & $\begin{array}{c}\text { DG size in } \\
\text { MW }\end{array}$ & $\begin{array}{c}\text { DG } \\
\text { location }\end{array}$ & $\begin{array}{c}\text { Line loss in } \\
\text { MW }\end{array}$ \\
\hline WODG & ---- & ---- & 0.88180 \\
\hline $30 \%$ & 2.61489 & 24 & 0.46046 \\
\hline $50 \%$ & 4.35815 & 22 & 0.36600 \\
\hline $60 \%$ (optimal) & 5.75688 & 21 & 0.34544 \\
\hline
\end{tabular}

Average load of the test system $=\sum$ load in MW in each hour 124

$=(6+5.19+5 \cdot 5+5 \cdot 5+5 \cdot 5+6 \cdot 5+6 \cdot 5+6 \cdot 5+8 \cdot 5+8 \cdot 5+10.5+10.5+10$.

$5+10.5+10.5+10.5+9+10+12+13+13+11+8+6) / 24$ 


\section{$=209.19 / 24=8.7163 \mathrm{MW}$}

Size of DG $=(8.7163+0.88180) * 60 \%=5.75688 \mathrm{MW}$

The cost benefit analysis is carried out (without considering environmental emissions and percentage of outage rate) for the above selected DG capacities which are in Table 3 being connected to their respective optimal locations. For base case NPV analysis fixed cost of $1 \mathrm{MW}$ DG plant is assumed at the rate of $20,00,000 \$ / \mathrm{MW}$. When DG is connected to the system it is not run at $100 \%$ of rated capacity throughout the day.

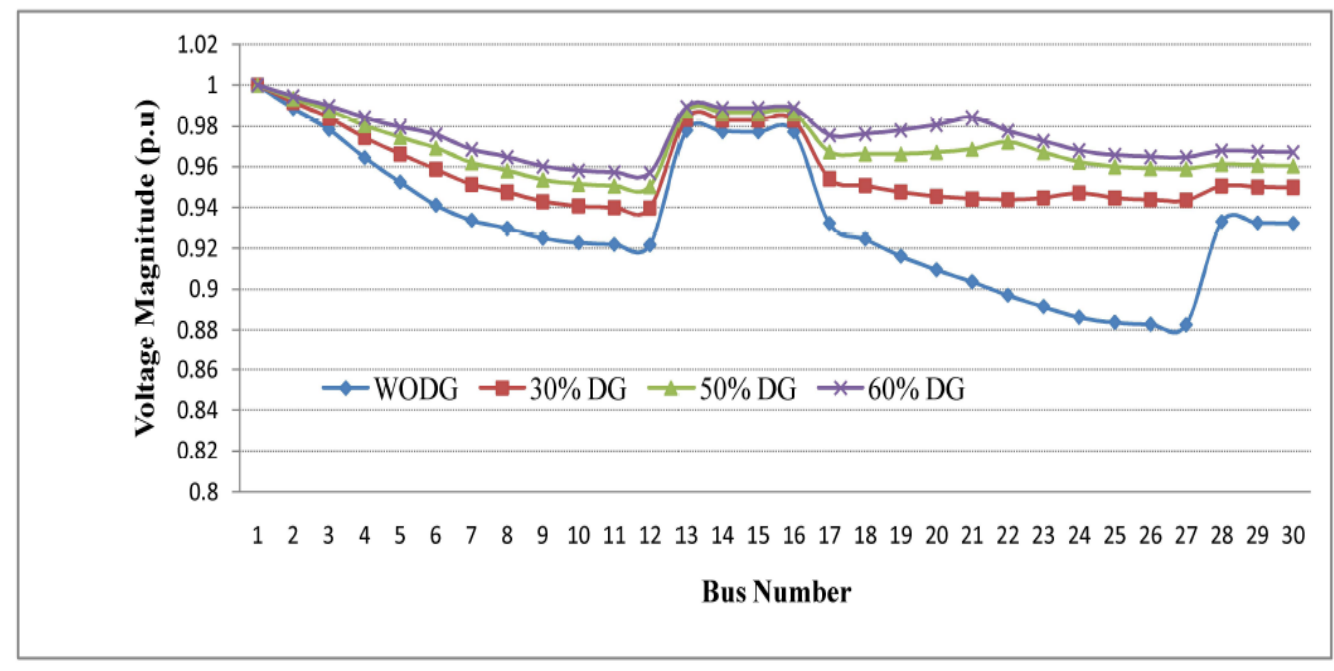

Fig 1: Impact of DG on voltage profile

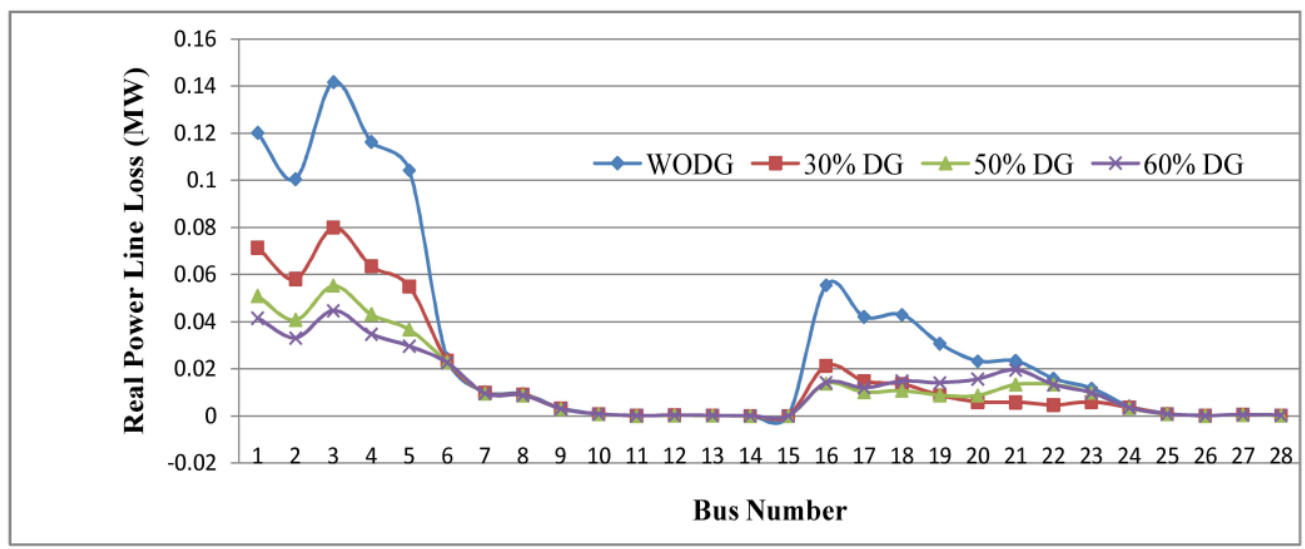

Fig 2: Impact of DG on line loss profile

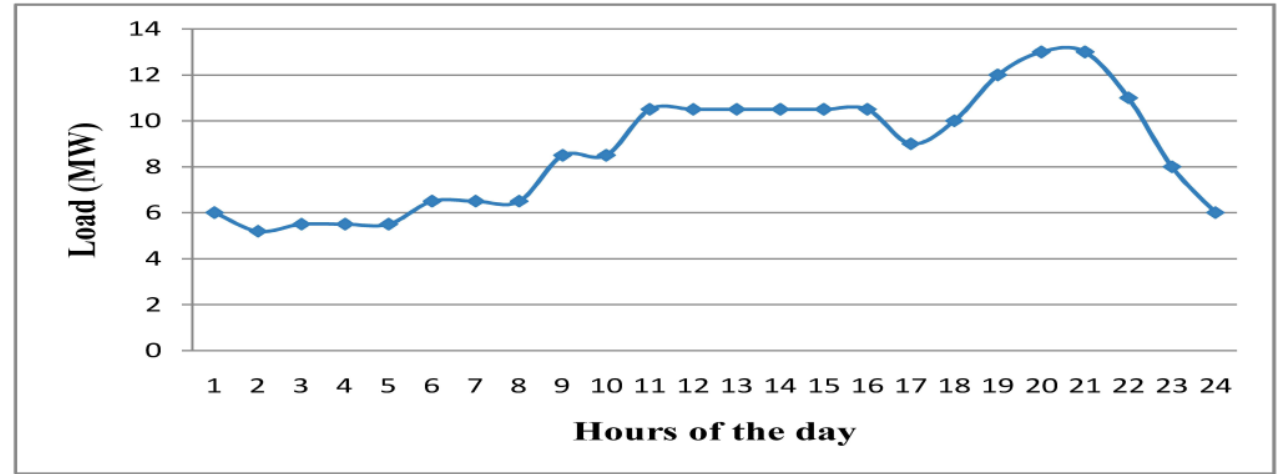

Fig 3: Daily load curve of the test system 
The hourly loading pattern for 24 hours of a day on DG may be scheduled as

\begin{tabular}{|c|c|c|}
\hline & $22 \mathrm{hr}$ to $24 \mathrm{hr}$ and $00 \mathrm{hr}$ to $04 \mathrm{hr}$ (06 hrs) & $30 \%$ \\
\hline 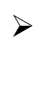 & $\begin{array}{l}04 \mathrm{hr} \text { to } 08 \mathrm{hr} \text { and } 12 \mathrm{hr} \text { to } 17 \mathrm{hr}(09 \mathrm{hrs}) \\
\text { rated capacity }\end{array}$ & $50 \%$ \\
\hline$D$ & $\begin{array}{l}08 \mathrm{hr} \text { to } 12 \mathrm{hr} \text { and } 17 \mathrm{hr} \text { to } 22 \mathrm{hr}(09 \mathrm{hrs}) \\
\text { rated capacity }\end{array}$ & $100 \%$ \\
\hline & $\begin{array}{l}\text { load factor (PLF) for a day }= \\
* \text { percentage of rated capacity u } \\
30+9 * 0.50+9 * 1) / 24=63.75 \%\end{array}$ & \\
\hline
\end{tabular}

The pattern of loading may vary but it will consider the PLF as $63.75 \%$ throughout all other calculations

$\mathrm{DG}_{\mathrm{kWh}}=\mathrm{P}_{\mathrm{DG}} * 24 * \mathrm{PLF}$

$\mathrm{KWh}$ loading of DG $=$ rating of $\mathrm{DG}$ in $\mathrm{KW} *$ hours of the day * PLF

\section{$=5.75688(60 \%) * 1000 * 24 * 0.637=88011 \mathrm{KWh}$ or units/day}

DG income has the two aspects, one is income from energy generated and the other is from saving of energy due to line loss reduction. The calculation procedure for those incomes as follow:

$\mathrm{DG}_{\mathrm{a} . \text { inc }}=\mathrm{C}_{\text {elect }} * 365\left(\mathrm{DG}_{\mathrm{kWh}}+\mathrm{P}_{\mathrm{LLR}} * \mathrm{PLF} * 24\right)$

Calculation procedure for optimal DG capacity:-

1. From above, 93278 units/day, calculated@ 0.088 \$/unit which is the assumed fixed tariff at prevailing rate of Distribution Company for domestic consumers for a year.

$=\$ 0.088 * 88011 * 365=\$ 2826913$

$\mathrm{P}_{\mathrm{LLR}}=$ Line loss without $\mathrm{DG}-$ Line loss with DG

$=0.88180-0.34544=0.5355 \mathrm{MW}=536.3 \mathrm{KW}$

2. Note that above KW saving is when the DG runs at full load. Calculating the income in the same manner as in (1) for a year

$=\$ 0.088 * 536.3 * 0.637 * 24 * 365=\$ 263350$

Annual income from DG $=\$ 2826913+263350=\$$ 3090263

Above procedure is repeated for $30 \%$ and $50 \%$ DG capacities.

Fundamental to finance is the concept of "time value of money," where the assumption is that money is worth more in your hand today then tomorrow. For example, money available now can be invested to generate interest and revenue which is a lost opportunity if one has to wait for money to have at their disposal. The NPV, or net present worth (NPW), of a time series of cash flows, both incoming (positive) and outgoing (negative), is defined as the sum of the present values (PVs) of the individual cash flows [16]. If all future cash flows are incoming and the only outflow of cash is the purchase price, the NPV is simply the PV of future cash flows minus the purchase price [16]. NPV is a valuable tool in discounted cash flow (DCF) analysis, is a standard method for using the time value of money to appraise long-term projects and is used for capital budgeting to measure the excess or shortfall of cash flows in present value terms once financing charges are met [16]. In this case, the financial benefit to LDCs of increased DG uptake at strategic locations on the distribution feeder is evaluated using NPV analysis. The NPV of a sequence of cash flows takes as input the cash flows and a discount rate or function and outputs a price; the converse process in DCF analysis - taking a sequence of cash flows and a price as input and inferring as output a discount rate (e.g. "break even" discount rate which would yield the given price as NPV) is called the yield, and is more commonly used in finance, e.g. bond trading [17]. In this paper, a planning period of twenty years was used to standardize the time horizon so that a NPV analysis can be performed and the financial benefits can be compared in present value terms. Below are the expressions used in the NPV analysis.

$$
\begin{aligned}
& \mathrm{C}_{\mathrm{DGO \& M}}=\mathrm{C}_{\mathrm{OMDG}} * \mathrm{DG}_{\mathrm{kWh}} * 365 \\
& \mathrm{C}_{\text {DGinstcost }}=\mathrm{P}_{\mathrm{DG}} * \mathrm{C}_{\text {DGcapcost }} \\
& \mathrm{C}_{\text {DGenvcost }}=\mathrm{DG}_{\mathrm{kWh}} * \mathrm{C}_{\text {emiscost }} * 365 \\
& \mathrm{C}_{\text {outage }}=\mathrm{DG}_{\text {aninc }} * \mathrm{R}_{\text {outage }} \\
& \mathrm{C}_{\mathrm{dep}}=\mathrm{R}_{\mathrm{dep}} * \mathrm{C}_{\text {DGinstcost }} \\
& \mathrm{DG}_{\text {inbtax }}=\mathrm{DG}_{\mathrm{a} . \text { inc }}-\mathrm{C}_{\mathrm{DGO} \& \mathrm{M}}-\mathrm{C}_{\text {outage }}-\mathrm{C}_{\mathrm{dep}} \\
& \mathrm{DG}_{\text {inaftax }}=\mathrm{DG}_{\text {inbtax }}-\mathrm{R}_{\text {tax }}\left(\mathrm{DG}_{\text {inbtax }}\right) \\
& \mathrm{DG}_{\mathrm{NPV}}=-\mathrm{C}_{\text {DGinstcost }}+\left(\mathrm{DG}_{\text {inaftax }}\right)
\end{aligned}
$$

For base case NPV analysis, it is assumed that the operation and maintenance cost $(\mathrm{O} \& \mathrm{M})$ and depreciation cost is $5 \%$ of DG installation/investment cost. The equipment cost will be written off to depreciation over a project life of 20 years. The tax on income is assumed as $10 \%$ per annum and a $10 \%$ rate of return per annum is expected as minimum but which may be nullified by the hike of electricity tariff at the same rate. To evaluate the impact of DG capacity on financial benefits, NPV analysis has been performed on $30 \%, 50 \%$ and $60 \%$ DG capacities. The financial analysis results for $30 \%, 50 \%$ and $60 \%$ DG capacities are given in Fig 4and Fig 5. From Fig 4 and Fig 5 it is observed that the year of cost recovery and return on investment is varying with variation of DG capacity, which represents a profitable operation.

\section{SELECTION OF SUITABLE DG TECHNOLOGY}

DG technologies can be classified as renewable and nonrenewable. Renewable include photovoltaic, wind, geothermal, tidal, ocean. Nonrenewable include internal combustion engine (gas or diesel or heavy oil), micro turbine, fuel cells [18]. Almost all renewable DG technologies are non dispatchable. For example wind turbine cannot be installed in 


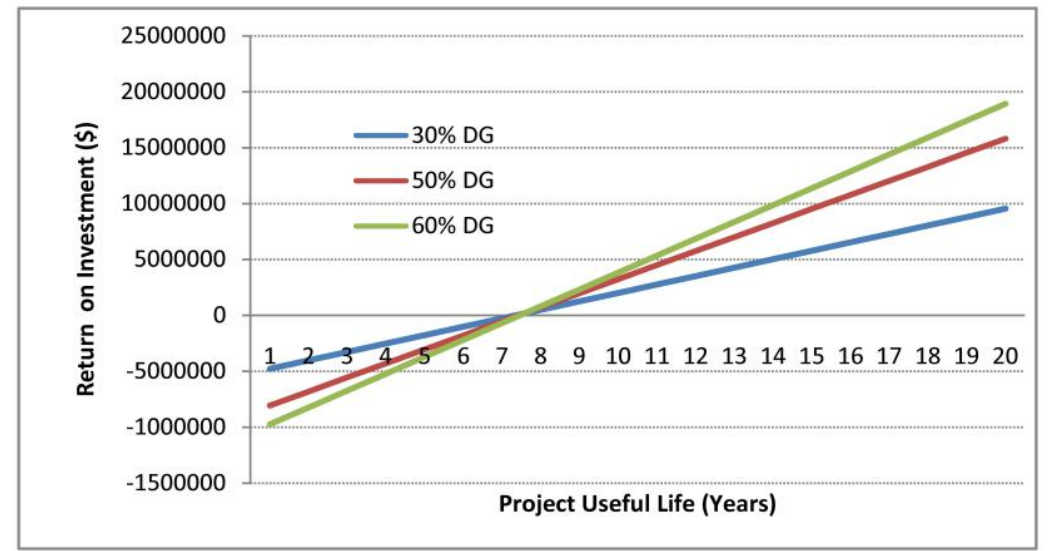

Fig 4: Illustration for return on investment with DG

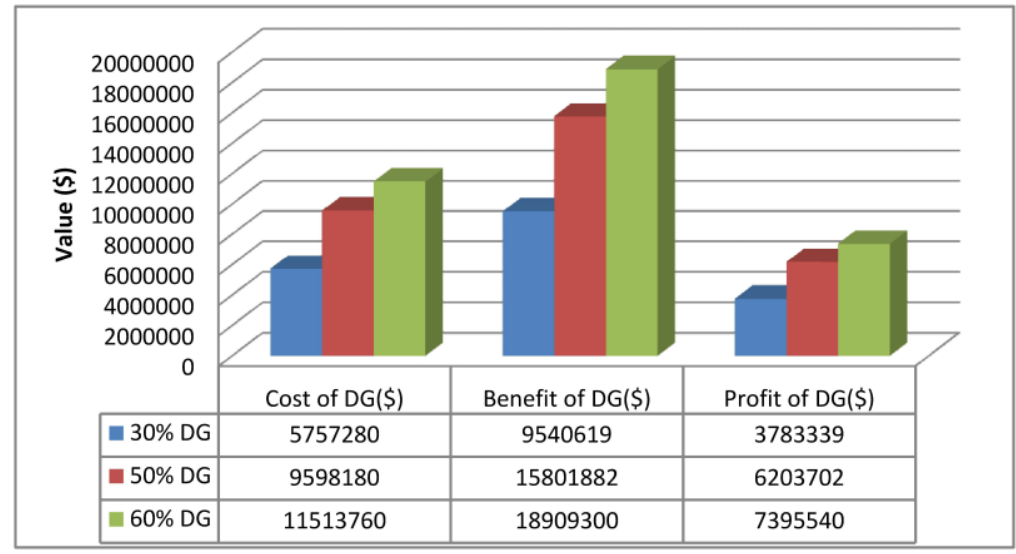

Fig 5: Summary of cost benefit analysis with DG

Table 4. Economic summary of some DG technologies [1723]

\begin{tabular}{|c|c|c|}
\hline $\begin{array}{c}\text { Type of } \\
\text { Generation } \\
\text { Technology }\end{array}$ & $\begin{array}{c}\text { Life Cycle } \\
\text { Emission } \\
\text { gCO }_{2} \text { eq/ kWh } \\
\text { Min } \sim \operatorname{Max}\end{array}$ & $\begin{array}{c}\text { Average Life } \\
\text { Cycle } \\
\text { Emission in } \\
\mathrm{gCO}_{2} \mathrm{eq} / \mathrm{kWh}_{\mathrm{e}}\end{array}$ \\
\hline F.F. Coal & $800 \sim 1000$ & 900 \\
\hline Oil Fired & $700 \sim 800$ & 750 \\
\hline Natural Gas Fired & $360 \sim 575$ & 467 \\
\hline PV & $50 \sim 73$ & 61.5 \\
\hline WT & $8 \sim 30$ & 19 \\
\hline Hydro & $1 \sim 34$ & 17.5 \\
\hline Bio-Mass & $35 \sim 99$ & 67 \\
\hline
\end{tabular}

areas where there is no steady wind or in hurricane or cyclone prone areas, same with the case of photovoltaic. So all DG technologies have not yet proven to be cheap, clean and reliable for field application. The economics and currently available DG technologies are summarized in Table 4. In the present study assuming the presumed benefits of DG technologies, a selection process is carried out for the implementation of project based on NPV analysis. Significant emission cost of each DG technology has been calculated based on [26] and presented in Table 4, where emission includes pollutants like $\mathrm{Co} 2, \mathrm{So} 2, \mathrm{Co}, \mathrm{No}_{\mathrm{x}}$. Based on Table 4, NPV analysis has been carried out for various DG technologies including environmental costs, and results are illustrated in Fig 6 and Fig 7. From Fig 6 and Fig 7, it is noticed that all DG Technologies doesn't yield financial benefits during the project period even though the emission cost is negligible for technologies like WT and PV (this is due to their higher initial investment cost as compared to other DG technologies). Table 5. sets out typical life-cycle $\mathrm{CO} 2$ emissions of the major forms of electric power generation technologies. Through the data in this table, it is found that $\mathrm{CO} 2$ emissions from coal and biomass technologies are far exceeded those of renewable energy technologies. 


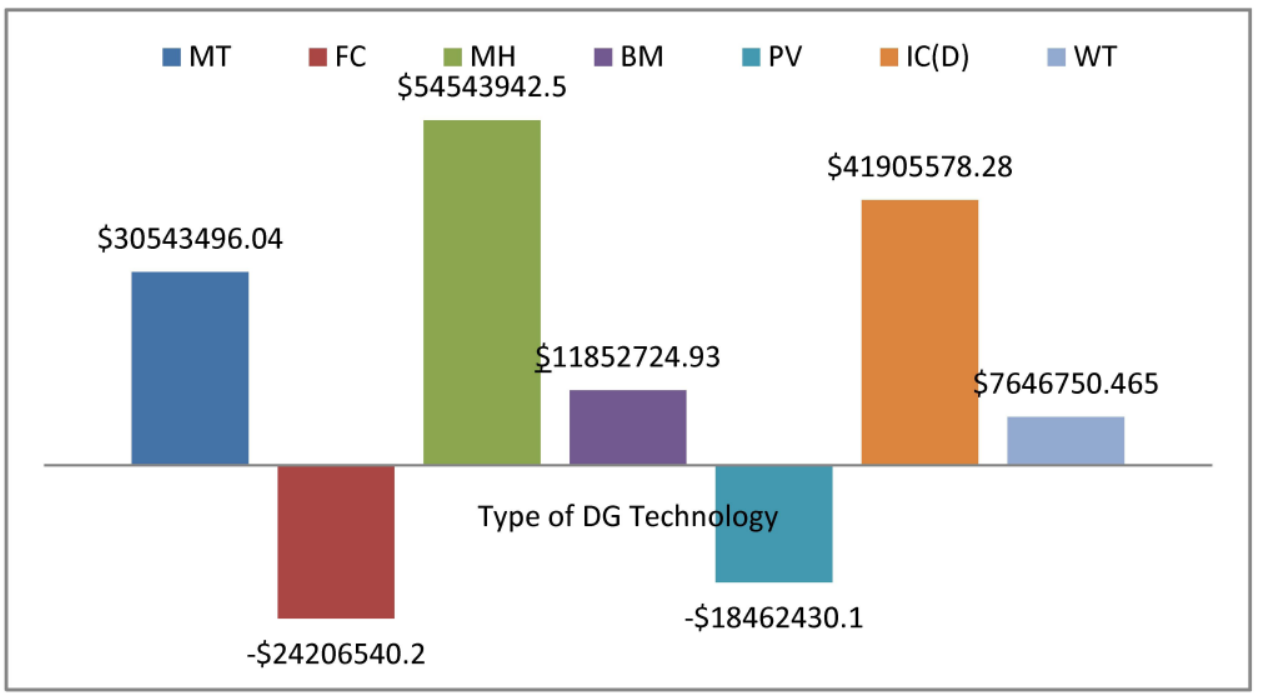

Fig 6: Summary of cost benefit analysis for various DG Technologies

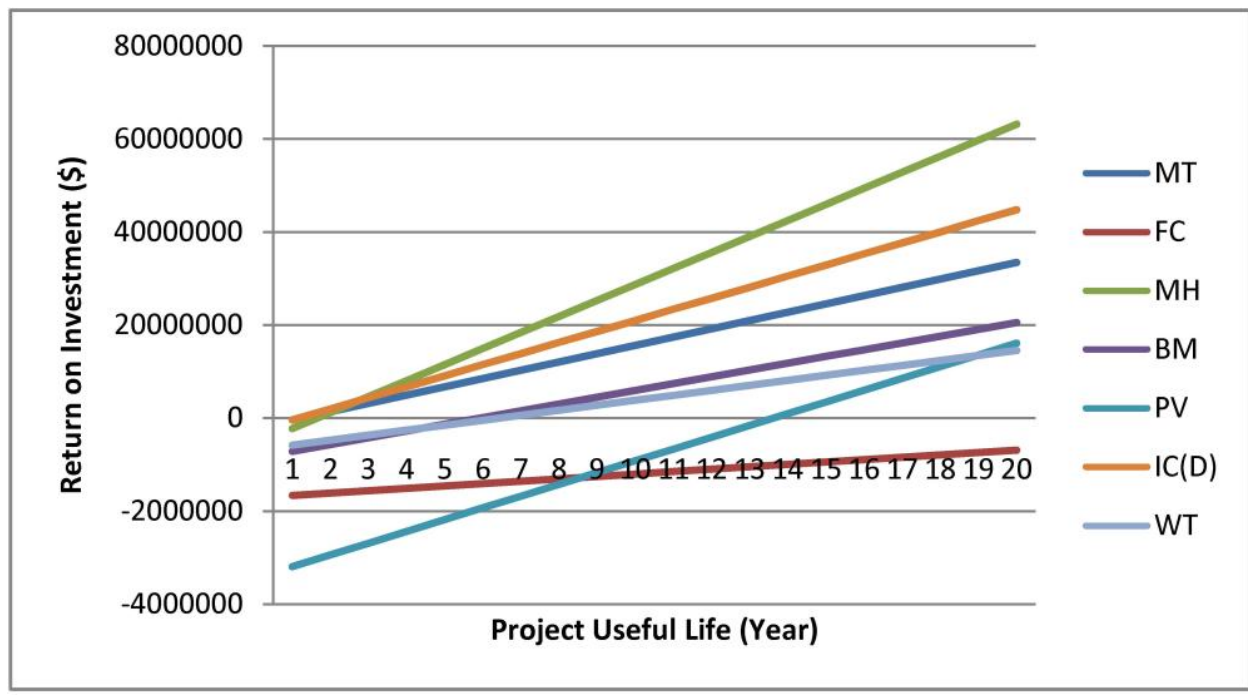

Fig 7: Illustration for return on investment for various DG Technologies

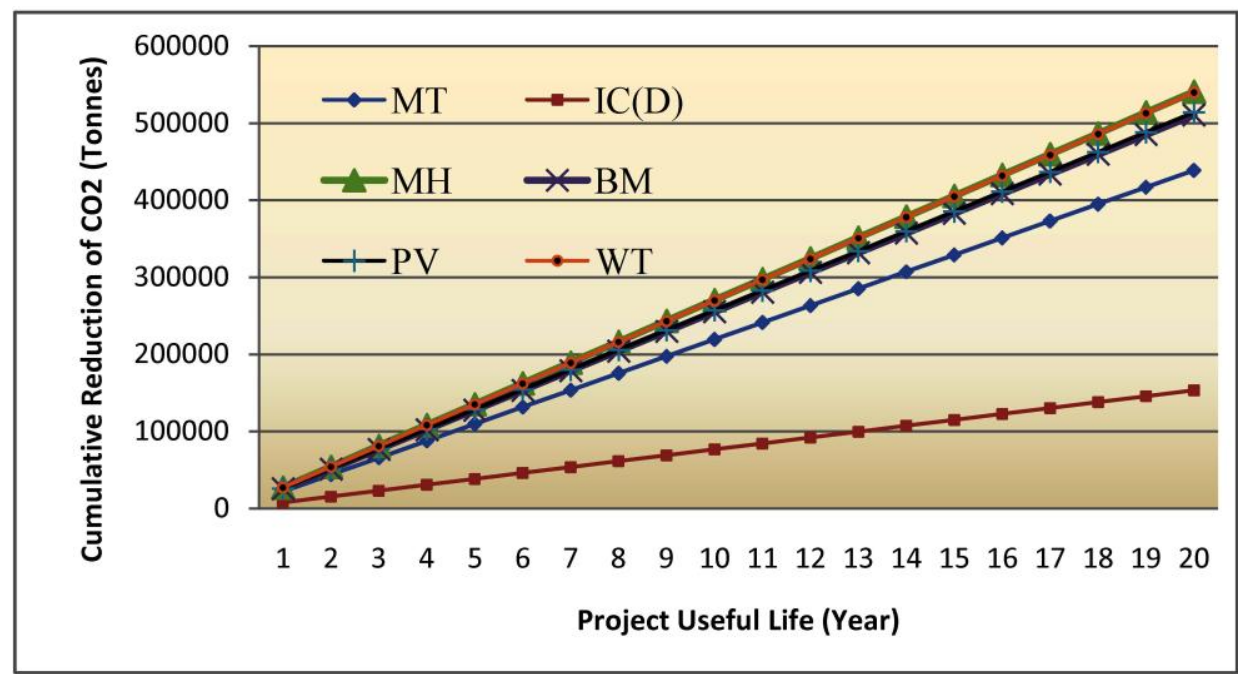

Fig 8: Cumulative reduction of $\mathrm{CO}_{2}$ over project period in the presence of various DG Technologies 


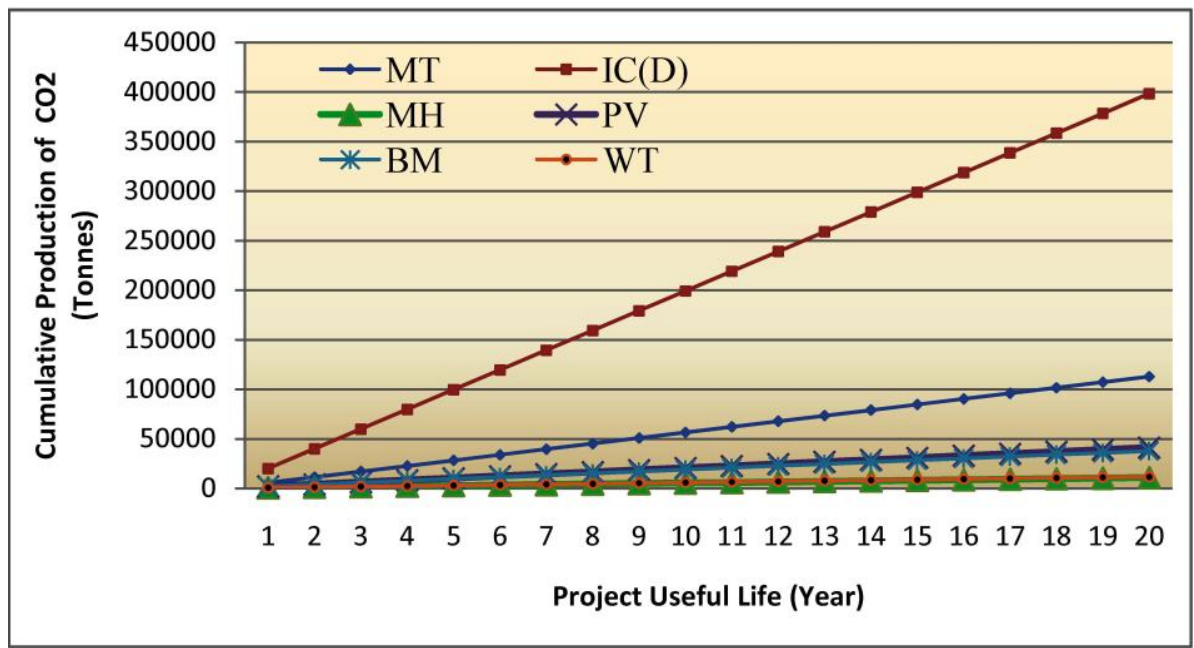

Fig 9: Cumulative production of $\mathrm{CO}_{2}$ over project period in the presence of various DG Technologies

Table 5. GHG $\left(\mathrm{CO}_{2}\right)$ Emissions from Different Generation Technologies

\begin{tabular}{|c|c|c|}
\hline $\begin{array}{c}\text { Type of } \\
\text { Generation } \\
\text { Technology }\end{array}$ & $\begin{array}{c}\text { Life Cycle } \\
\text { Emission } \\
\mathrm{gCO}_{2} \mathrm{eq} / \mathrm{kWh}_{\mathrm{e}}\end{array}$ & $\begin{array}{c}\text { Average Life Cycle } \\
\text { Emission in } \\
\mathrm{gCO}_{2} \mathrm{eq} / \mathrm{kWh}_{\mathrm{e}}\end{array}$ \\
\hline F.F. Coal & $800 \sim 1000$ & 900 \\
\hline Oil Fired & $700 \sim 800$ & 750 \\
\hline Natural Gas & $360 \sim 575$ & 467 \\
\hline Fired & & 61.5 \\
\hline PV & $50 \sim 73$ & 19 \\
\hline WT & $8 \sim 30$ & 67 \\
\hline Hydro & $1 \sim 34$ & \\
\hline Bio-Mass & $35 \sim 99$ & \\
\hline
\end{tabular}

Meanwhile it is observed that PV, WT, MH and FC technologies are being regarded as an environmentally friendly generation type. Cumulative reduction of $\mathrm{CO} 2$ over the project period has been calculated based on [27, 28]. Cumulative reduction as well as production of $\mathrm{CO}_{2}$ over the project period in the presence of different DG technologies is illustrated in Fig 8 and Fig 9.

\section{CONCLUSIONS}

In this paper, impact of DG on techno economic benefits has been studied. Using 30-bus radial distribution test system and
DG capacities of $30 \%, 50 \%$ and $60 \%$ of total load plus losses, the voltage profile and the real power loss has been analyzed and significant improvement in voltage profile and reduction in line loss is observed. For optimal utilization, a DG capacity should be chosen that it has to operate with the capacity of $60 \%$ of total load plus losses. Profits have been estimated in financial terms by performing NPV analysis for 20 years of project period. It can be concluded that a distribution company will definitely make profit only if a suitable size DG plant is strategically placed in the distribution system. For the implementation of project, a selection process is carried out for suitable DG Technology and estimated the financial benefits by considering emission cost and outage cost of DG. It is recognized that selection of technology represents only a technical option. The underlying economic reality and financial benefits will determine whether this option is used or not. In view of financial benefits not all DG technologies are suitable for implementation of the project. It is observed that greater use of renewable energy DG technologies can significantly reduce the carbon intensity $\left(\mathrm{CO}_{2}\right.$ emission $)$ of electricity generation in power sectors that are dominated by fossil fuel power plants. Please note that, while the underlying method and evaluation of DG in a radial distribution system can be applied elsewhere. But, the financial results and environmental benefits obtained in this study are purely subjected to literature which cannot be generalized.

\section{REFERENCES}

[1] Y H Song, G S Wang, A T Johns, PY Wang. Distribution Network Reconfiguration for Loss Reduction using Fuzzy Controlled Evolutionary Programming. IEE Proc. Gene. Trans. Dist., 1997; 144: 345-350.

[2] YG Hejaz, MMA Salaam, AY Chicano. Adequacy Assessment of Distributed Generation Systems using Monte Carlo Simulation. IEEE Trans. On Power Systems 2003; 18: 48-52. 
[3] W EI-Khatan, MMA Salaam. Distributed generation technologies, definitions and benefits. Electric Power System Research 2004; 71:119-128.

[4] A Poullikkas. Implementation of distributed generation technologies in isolated power systems. Renewable and Sustainable energy 2007; 11:30-56.

[5] T Griffin, K Osmotic, D Secrets, A Low. Placement of dispersed generation systems for reduced losses. In Proc. IEEE $33^{\text {rd }}$ Annul. Hawaii Int. Conf. Syst. Sciences (HICSS) 2000; $1446-1454$

[6] P Chiradeja. Benefit of distributed generation: a line loss reduction analysis. T\&D Conference and Exhibition: Asia and Pacific 2005; 3:1401-1407.

[7] SS Pati, PK Modi. Loss minimization of distribution system using distributed generation. Cogeneration and Distributed Generation 2009; 24: 23-47.

[8] GP Harrison, AR Wallace. Optimal power flow evaluation of distribution network capacity for the connection of distributed generation. IEE Proc. Gen. Trans. and Dist., 2005; 152: 115-122.

[9] A Silvestri, A Berizzi, S Buonanno. Distributed generation planning using genetic algorithms. In Proceedings of IEEE International Conference on Electric Power Engineering, Power Tech., Budapest 1999; 99

[10] W EI-Khatan, K Bhattacharya, Y Hegazy, MMA Salaam. Optimal investment planning for distributed generation in a competitive electricity market. IEEE Tans. On Power Systems 2004; 19: 1674-1684.

[11] Jeo-Hao, Teng, Yi-Hwa, Liu, Chia-Yen, Chi-Fa Chen. Value based distributed generation placements for service quality improvements. Electrical Power and Energy Systems 2007; 29: 268-274.

[12] W Rosehart, E Nowicki. Optimal placement of distributed generation. In $14^{\text {th }}$ Power Systems Computation Conference 2002; 11: 1-5.

[13] BA Desouza, JMC De Albuquerque. Optimal placement of distributed generators in network using evolutionary programming. In proc. Of Trans. And Dist. Conference, Latin America, IEEE/PES 2006: 1-6.

[14] DQ Hung, N Mithulanathan, RC Bansal. Analytical expressions for DG allocation in primary distribution networks. IEEE Trans. on Energy Conversion 2010; 25: 814-820.
[15] H Hedayati, SA Nabaviniaki, A Akbarimajd. A method for placement of DG units in distribution networks. IEEE Transactions on Power Delivery 2008; 23:1620-28.

[16] Net Present Analysis. http://en.wikipedia.org/wiki/Net_present_value

[17] IEEE Application Guide for IEEE Std. 1547, IEEE Standard for Interconnecting Distributed Resources with Electric Power Systems (2008).

[18] N Jenkins, R Allan, P Crossley, D Kirschen, G Strbac. Embedded generation. IEE Power and Energy. Series 31 London; 2000.

[19] AGL. Comparison of large central and small decentralized power generation in India. Golden, $\mathrm{CO}$ : Antres Group Ltd. And NREL; 1997.

[20] EIA. Energy Information Administration. U.S Department of energy. Annual Energy Outlook; 2002.

[21] J Gregory, S Silveira, A Derrick, P Cowley, C Allinson, O Paish. Financing Renewable Energy Projects: A Guide for Development workers. Intermediate Technology Publications. London; 1997.

[22] Morris, Ellen. Analyses of Renewable Energy retrofit Options to Existing Diesel Mini Grids. APEC Singapore; 1998.

[23] EM Petrie, HL Willis, M Takahashi. Distributed Power Generation in Developing Countries. 2002. Available on www.worldbank.org/html/fpd/em/distribution-abb.pdf.

[24] N Ravindranath, DO Hall. Biomass Energy and the Environment: A Developing Country Perspective from India. Oxford University Press, oxford; 1995.

[25] UN. Energy Issues and Options for Developing Countries: Taylor and Francis. New York; 1989.

[26] K Qian, C Zhou, Y Yuan, X Shi, M Allan. Analysis of the Environmental Benefits of Distributed Generation. IEEE Power and Energy Society Meeting- Conversion and Delivery of electrical energy in the $21^{\text {st }}$ century 2008; $1-5$.

[27] D Weisser. A guide to life-cycle greenhouse gas (GHG) emissions from electric supply technologies Energy 2007; 32:19; 1543- 1559 .

[28] IEA. $\mathrm{CO}_{2}$ Emissions from Fuel Combustion Highlights, IEA Statistics, 2011 edition. Available on www.iea.org/co2highlights. 